\title{
Blog-based professional development of English teachers in Mumbai: The potential of innovative practice under scrutiny
}

\author{
Atiya Khan \\ RMIT University, Australia
}

\begin{abstract}
The professional development of teachers in India is still, by and large, based on formal and outdated professional learning traditions, often characterised by crash courses and one-off workshops. In education, blogs have proven to be an effective means of establishing and maintaining collaborative learning networks and helping members reflect on their professional practices. Information and communications technology (ICT) enabled practices of teacher professional development is still in its infancy in India. Moreover, there is limited research in India to secure foundational understanding of how and in what ways teachers of English in India use blogs for their professional development. This study explores the use of teacher reflective practice, teacher networking, and teacher collaboration, beyond formal ICT training, through blog-based professional development of English teachers in the Mumbai region of India. Using data collected from 32 teachers from three private schools in Mumbai, through ICT interactive workshop observations, questionnaires, interviews, and blog comments, this action case study explains whether and why blogging, as a learning community, has the potential to add significant value to existing professional development of English teachers in Mumbai.
\end{abstract}

\section{Introduction}

The most crucial requirement for effective learning of English is the English teacher, but concerns have been raised about the teaching competency of English language teachers in India (Reddy, 2012). Consequently, professional development is one major area which needs significant changes if quality English teachers in India are to become available (Bolitho \& Padwad, 2012). The development of teachers' ICT skills, knowledge, and attitudes has to be encouraged through innovative training and professional development strategies (Padwad \& Dixit, 2014). As many researchers have attested, the use of Web 2.0 networking in teacher professional development offers effective learning environments as teachers can deal with new knowledge in a dynamic, contextual, constructive, and collaborative way (Bell \& Morris, 2009; Duncan-Howell, 2009; Prestridge, 2008).

The rationale for this study is to investigate the potential of blog-based teacher reflection, teacher networking, and teacher collaboration for professional development. Specifically, it studies their ICT attitudes, the barriers they encounter in the use of ICT for teaching purposes, and their professional development practices and needs. It explores the potential of blogs as a forum for teachers to connect with each other, aid the sharing of best ICT practices, and provide access to new ideas for teaching. It sought to encourage English teachers in Mumbai to take the lead, use ICT to teach ICT, educate each other, and not just follow.

This study aims to address four research questions:

- What are the attitudes of English teachers in Mumbai towards the use of ICT for classroom instruction and their professional development?

- What are the major barriers to effective integration of ICT in teaching English and professional development of English teachers in Mumbai?

- What do teachers in Mumbai perceive they need in order to develop their professional competence in ICT?

- What is the potential of web-based reflection, networking, and collaboration for the professional development of English teachers in Mumbai? 


\section{Review of related literature}

The increasing possibilities of using ICT for communication enable teachers to reflect, share, and advance their current perspectives on professional development (Holmes, Preston, Shaw, \& Buchanan, 2013). Blogs foster better teacher interaction with features of asynchronous conversation and equal voices in professional development (Zandi, Thang, \& Krish, 2014). Murugaiah (2010) conducted a study on the role of blogging in teachers' professional development and its function of developing computer-assisted English language teaching skills. English language teachers from Malaysian Smart Schools, who shared their ideas and practices through blogging, were engaged in Murugaiah's study. The finding suggests that interaction through the blog led the teachers to be exposed to the required skills for computer-assisted teaching and benefited them to enhance their competencies. Blogs, which can function as online personal journals, can act as incentives in galvanising teachers to record and reflect on their teaching processes (Lunyal, 2012). Ray and Hocutt (2006) in a study focused on the K-12 teachers' use of blogs, found that blogs:

[F]unctioned as reflective journals where teachers could write about and reflect on events occurring in their classrooms. Entries demonstrated a process of continuous reflection about ... students and about [teachers'] knowledge and understanding of ... issues impacting practice. (p. 25)

Loving, Schroeder, Kang, Shimek, and Herbert (2007) also examined how blogs could play a role in a teacher networking project, and noticed that blogs assisted the construction of a network of the teachers involved in the project. The resources and ideas were shared by teachers through the blogs, which allowed teachers to reflect on their own practices. Stiler and Philleo (2003) studied the use of blogs as online journals in two groups of pre-service and in-service teachers and learned that both students and teachers thought of blogging as a unique tool that could boost reflective development and construct online communities. However, to be successful, online reflection, networking or collaboration time needs to be provided for teachers to test new learning methods and to receive follow-up support as they face problems of implementing changes (Duncan-Howell, 2009).

Research literature worldwide on effective professional development supports teacher learning practices that are consistent, followed-up, supported by the school, and done collectively by all teachers (Garet, Porter, Desimone, Birman, \& Yoon, 2001). The importance of supportive policy solutions, programs and opportunities was also substantiated by an investigation from Montenegro (Popovic \& Subotic, 2012); a country with open legislation and highly structured governmental provisions for teachers' professional development. When underlining the worth and importance of policy support for teacher professional development, Popovic and Subotic (2012) found in their study that the need for school-based teacher professional development was identified and prioritised at the ministry level. Carr and Chambers (2006) suggest that online communities have been slow in developing as an effective medium of teacher professional development due to two main reasons: "Schools do not adequately value collegial reflective sharing of practice, and classroom teachers do not use online communication tools as an integral part of their professional practices” (p. 269). Other known factors that influence the extent of teachers' ICT integration are the lack of time and resources to develop new pedagogical practices (Groff \& Mouza, 2008).

An ICT-enabled professional learning environment for teachers in India cannot be created overnight as teachers need to experience appropriate and relevant input. In the findings from case studies of the introduction to the Intel Teach Essentials Course-a professional development program focused on integrating information and communication technologies (ICT) into project-based learning-into six schools in India, Chile, and Turkey, Light (2009) advocates that the mere introduction of a new tool, new practice, or new policy in the classroom is not enough. Light (2009) further suggests that change is essential and possible only "by deeply reshaping life in the classrooms-from educators' beliefs about learning to the relationships that make up the school community" (p. 12). ICT attitudes also are among those important factors which influence the teachers to adopt ICT (Bordbar, 2010). Positive attitudes typically persuade teachers missing ICT know-how to gain knowledge of the competencies for implementing ICT in the teaching-learning environment (Narasimham, 2012). Rajasekar and Vaiyapuri (2007) studied computer knowledge and attitudes towards computers of 670 higher secondary school teachers in the Cuddalore district of Tamilnadu, India. Their survey demonstrated that $60 \%$ of the teachers had positive attitudes 
towards computers, even though teachers' computer knowledge was low. Teachers become effective ICT integrators through positive teacher attitude, thereby feeling more comfortable with using and integrating ICT into their pedagogy (Kumar \& Kumar, 2003). A lack of positive attitudes may give rise to stress and anxiety; as teachers may feel less confident and more uncomfortable with technology (Kulkarni, 2012; Rajasekar \& Vaiyapuri, 2007). When schools in India and their teachers realise and value the need of using ICT, and more importantly, achieve the benefits thereof, infrastructure and training will be worthwhile.

Teachers in India are in a constant struggle to reconcile the theory of their professional learning with their classroom teaching practices (Padwad \& Dixit, 2014). In a typical short-term ICT workshop for teachers in India, an external trainer models instructional practices for teachers so that teachers can then adapt the model to their own situation. Such workshops are often ineffective because of the lack of contextual considerations before modelling and the over-reliance on the teacher adaptation of existing practices (Prince \& Barrett, 2014). In many cases, the knowledge from this formal and traditional experience is short-term as teachers develop ICT knowledge, but rarely apply what they were exposed to and reflect on the experience (Padwad, 2008). Several professional development initiatives for teachers in India have failed to generate their anticipated outcomes; they highlighted the drawbacks of traditional ICT training but presented little assistance in transforming what happens in the classroom and afforded no opportunities for teachers to practice what they learn (Padwad \& Dixit, 2008). The narrow yet long established practice of teacher professional development in India also misses a crucial point - the need for teachers to take responsibility for their own learning. Teacher professional development is the most successful when it is decentralised so that the teachers have some element of command, control, and ownership (Borko, 2004). Pandit-Narkar's study (2012) highlights how the member teachers' own efforts enabled them to take advantage of the District English Centre established in their town, under the Indian education ministry's scheme for initiating continuing professional development (CPD) tasks. Pandit-Narkar's (2012) study of the District English Centre at Nellore also demonstrates that the encouragement and opportunities brought in by the school managers and/or education ministry considerably increased the effectiveness and success of the teachers' professional development initiatives.

The spirit of learning by doing, by collaborating with other teachers, by breaking out of intellectual isolation, and by sharing experiences and insights with others in the field is mostly missing from professional development practices of English teachers in India. However, recent research in India, on the professional development of teachers, is starting to yield a consensus concerning the social characteristics of effective teacher learning (Gupta, 2014). Bedadur (2012), researching the use of mobile phones by rural teachers of English in Karnataka, for their professional learning, described that "the pedagogical design of a professional development plan has to be collaborative to succeed. Moreover, it has to be an initiative driven by the participants” (p. 94). Yet, little is known in India about the teachers' use of Web-based networking and collaboration for their professional development (Chattopadhyay, 2013; Mitakshara, 2009). If schools in India wish to actualise quality education, then they and their teachers need to reconsider their professional learning approaches and realign their learning with the pedagogical potentials that Web 2.0 technologies offer. Moreover, a shift in attitudes and actions is necessary, and teachers are the primary means of addressing and resolving this professional development crisis.

Blogging can offer new avenues for professional learning by providing teachers with social learning opportunities. Of the various Web 2.0 networking technologies available, blogging was selected to support the teachers in this study for several reasons. Blogs have the potential to be a useful Web 2.0 instrument for teachers to develop a private or public discussion space that supports their reflection and collaboration (Henderson, 2004). Using blogs is one way to encourage teachers to communicate with other teachers on what is working and how they can integrate fresh ideas into their existing teaching strategies (Hall \& Davison, 2007). Teachers identify online networks to be a convenient means of finding like-minded professionals and reduce professional isolation (Sari, Lim, \& Pagram, 2010). With blogging, the participants can be in control of their own professional development and establish possibilities for learning within their work, time and context. Research on the use of blogs for the professional development of teachers in India is limited, and no study has focused particularly on English teachers in Mumbai. Therefore, my research study, investigating the potential of blog-based reflection, networking and collaboration, for the professional development of English teachers in Mumbai, is both timely and crucial. 


\section{Research methodology}

\section{Interpretive paradigm}

The methodology used in this study combines action research with an interpretive case study approach. Interpretive paradigm studies individuals with their different opinions, dissimilar attitudes, diverse human behaviours, and their unique characteristics (Cohen, Manion, \& Morrison 2007). I selected interpretive paradigm since it could help me to understand and explain the teachers' ICT practices, ICT perspectives, ICT barriers, and ICT needs within the context that regulated their professional development (Merriam, 1998). This gave me opportunities to seek to understand and make sense of others' perspectives which were shaped by their contexts.

Interpretive research empowers the participants and positions both researcher and the participants' views in a subjective context (Cohen et al., 2007). The interpretive study's main principle is that research can never be quantitatively discerned from the outside rather it must be observed from inside through the direct experience of the people. Researchers in this paradigm seek to understand rather than explain. The key practices applied in this methodology are participation, collaboration, and engagement (Henning, van Rensburg, \& Smit, 2004). Therefore, an interpretive paradigm requires a more personal, interactive means of data collection, such as observations and interviews.

The interpretive paradigm enabled me to construct rich local understandings of the pedagogical experiences of English teachers in Mumbai and of the cultures of the classrooms, schools and the communities they serve. With this understanding, I will be determined to explore in-depth the range of issues related to teachers' attitudes, beliefs, barriers and motivations in relation to ICT integrated teaching. And I believe this exploration could be best achieved with an interpretive (subjective) study of the experiences and beliefs of English teachers in Mumbai.

\section{Case study}

I have adopted a case study methodology, gathering qualitative data from open-ended questionnaires, participant observations, semi-structured interviews, and blog comments. Cohen, Manion, and Morrison (2007) demonstrate that case studies can be used to recommend changes for development at the individual, professional or institutional level, as information obtained from case studies are "strong in reality" and "a step to action”(p. 256). Researchers such as Hew and Brush (2007) and Light (2009) call for further and intensive research on the use of ICT in Indian schools, recommending case study research design as a way to address the lack of local understanding. A case study methodology is employed to understand in depth the potential of blog-based professional development of English teachers in Mumbai. Thirty-two English teachers teaching primary and secondary students in three private schools in Mumbai participated in this study. Their ICT integrated teaching practices, ICT knowledge, ICT attitudes, ICT barriers and ICT suggestions, within their traditional professional development practices, are investigated.

As Flyvberg (2011) states, choosing to do a case study is not so much a methodological choice, but rather a choice of what to study (the unit represented by the case). My case study examines whether blog-based collaboration facilitates teacher professional development (the case) of English teachers (the unit) in Mumbai. The ICT experiences of 32 teacher-participants are presented as a case study to highlight the intensity of issues, conditions and processes that impact the practice of blog-based professional development. The case to be investigated is the perception, participation and involvement of teachers in blog-based reflection, networking, and collaboration. It is not the aim of the study to develop separate detailed case studies of all the 32 teacher-participants involved in the study, but to develop a richer understanding of the nature of teacher participation in the blog for their professional development. This holistic case study focuses on the experiences of 32 teachers, presenting their perspectives and participation in the blog-based community for their professional development.

\section{Action research}

Action research is very much an interpretive method, as the researcher is part of the research. Unlike a case study, action research allows for the creation of change whilst simultaneously studying the effects (Avison, 
Baskerville, \& Myers, 2001; Miles \& Huberman, 1994). The action research method acknowledges that knowledge doesn't develop in a vacuum but has to be applied in practice and only then can the benefits of it are fully realised (Baskerville \& Myers, 2004). Further, this method of research is part of a philosophy that "sees human beings as co-creating their reality through participation, experience, and action" (Denzin \& Lincoln, 1994, p. 206). The action research in this study is driven by the researcher with a view to reflecting and improving practice; wherein the participants evaluate the innovation and also may identify the challenges (if any) in the process.

Action research blends inquiry and application into a seamless whole. This enables me, as a researcher, to effect change simultaneously while collecting and interpreting data. Action research thus appears as an appropriate methodology for this study. It fits with my interpretive philosophical beliefs and offers the opportunity for active intervention as a researcher.

\section{Participants and selection criteria}

The study can be best characterised as small-scale and in-depth. I have collected my data from three established private schools in Mumbai. I selected schools to visit that confirmed most closely to four criteria: the schools should be located in Mumbai, privately administered, the medium of instruction in the schools should be English, and the schools should provide both primary and secondary education.

The study comprises 32 English teachers in Mumbai, teaching in grades 3-10 in the 2014 to 2015 academic calendar. The teacher-participants attended ICT interactive workshops (conducted by me in their schools) and completed questionnaires. From this population, I selected 10 participants for the interviews. I used intensity sampling in conjunction with random sampling. This means that after observing my participants' attitudes and interaction during the workshop, and after analysing their responses in the questionnaires, I selected a subset of 10 intense cases for more in-depth analysis. With the help of workshop field notes and questionnaire responses, 5 participants with positive ICT perceptions, ICT attitudes and ICT experiences, and 5 participants with well explained negative ICT perceptions, ICT attitudes and ICT experiences were selected for the interviews. This equal emphasis on both viewpoints resulted in two teacher groups forming positive and negative representations of ICT perceptions, ICT attitudes and ICT experiences of the teacherparticipants in this study. Intensity sampling allowed me to select a small number of rich cases that provide in-depth information and knowledge of my research interest. As Patton (2002) points out, intensity sampling requires "prior information" and "exploratory work" (p. 172) to be able to identify intense examples. Therefore I gathered prior information about my participants and explored the extent of their relevance to this study through participant observations during the ICT training workshops and also through their questionnaire responses.

\section{Data collection strategies}

I have collected data through the blog, participant observation field-notes, questionnaires, and interviews.

\section{Blog}

Prior to conducting ICT interactive workshops, I created an ICT blog (Figure 1) specially designed as a teaching resource for English teachers in Mumbai.

My goals for establishing the blog-based version of teacher professional development were:

- $\quad$ to enable English teachers in India to gain experience and knowledge of blog-based professional learning,

- $\quad$ to motivate the teachers to participate in the blog discussions,

- to enhance the teachers' ICT competencies,

- $\quad$ to help the teachers to understand how to integrate ICT into a teaching environment,

- to encourage teachers to take responsibility and control over their own learning experiences, and most importantly, and

- $\quad$ to know whether blogs enable reflective dialogue, networking, and collaboration among English teachers in Mumbai. 


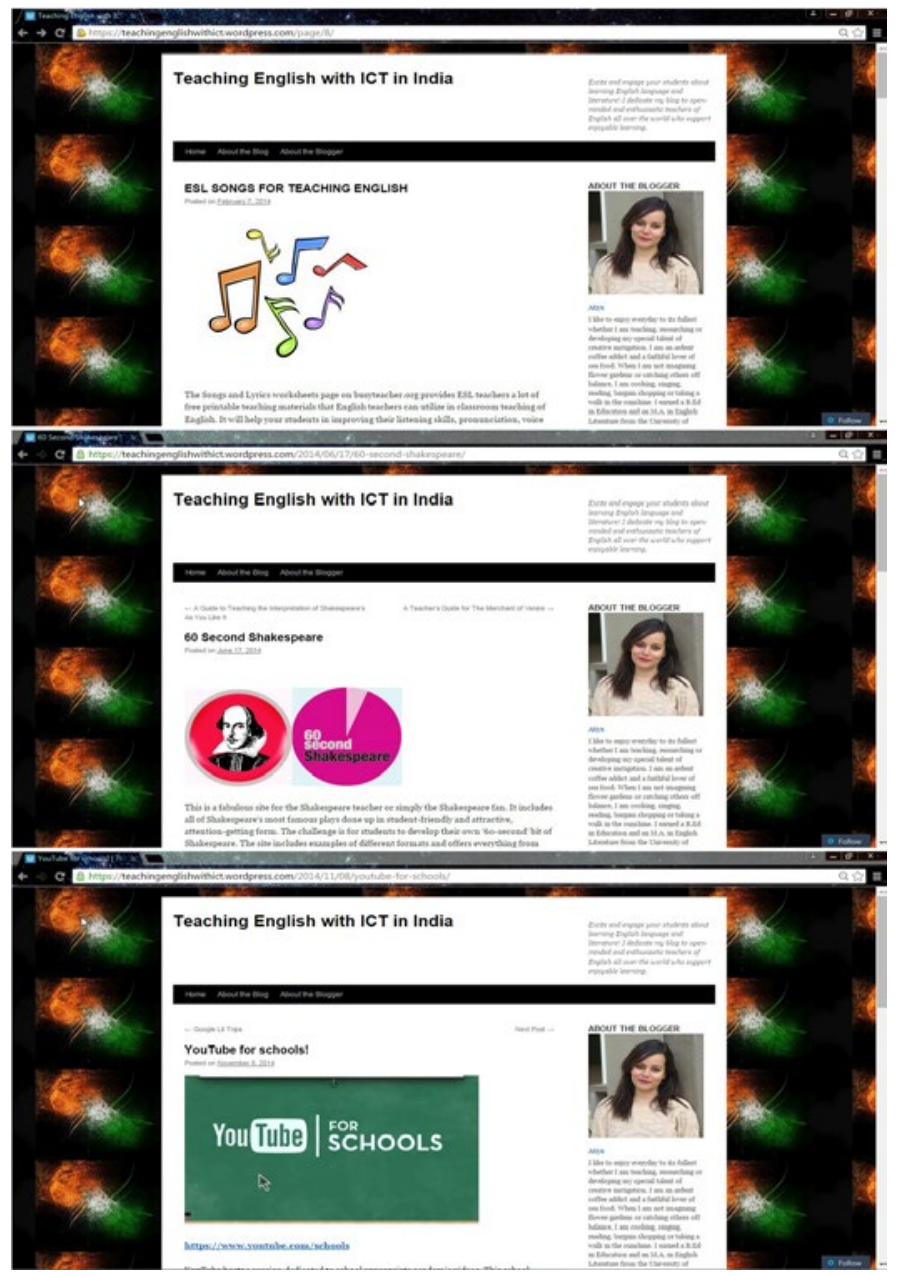

Figure 1. Blog screenshots

I maintained the blog from October 2013 until Feb 2015. During this period I published a total of 97 posts on the blog, comprising: articles, lesson planning resources, teaching materials, and links to audio-visual resources that were useful for ICT integrated teaching of English in Mumbai. Every post was divided into categories, such as drama, evaluation, Facebook, games, iPad apps, lesson plans, podcast, PowerPoint, puzzles, songs, TED, worksheets, YouTube, and so on. In addition, every post had a grammar or vocabulary focus. As a facilitator of the blog, I summarised the main ideas and themes and posed probing questions to keep the dialogue with blog members flowing. The blog members received notifications of new posts by email to keep the blog fresh in teachers' minds. Teachers were able to utilise teaching materials published on the blog and also could have an open conversation with each other.

Teachers' participation in the blog was on a voluntary basis. The blog data was gathered using teachers' comments on the blog from July 2014 and continued until February 2015. All the participants had an opportunity to use the blog for collectively reflecting and sharing their ICT experiences. There were no particular tasks for teachers to complete on the blog - they were simply asked to use the blog voluntarily to write about ICT topics they wanted to share with others or to ask questions to others. Only I could add new blog posts to the blog. However, the teacher participants could post comments on the blog posts or embed links.

\section{ICT interactive workshop observations (field-notes)}

I conducted ICT interactive workshops for 32 English teachers in three schools of Mumbai on 24 June 2014, 18 July 2014, and 1 August 2014. The objective of the workshops was to introduce the participants to the pedagogical potential of blogging as an asynchronous professional development practice of English teachers for ICT integrated teaching so that the potential of using online networks for teacher professional 
development in Mumbai becomes a possibility. Also, I wanted the teachers to use my workshop as an informal and liberal platform to freely share and discuss their ICT views, experiences (good and bad), and suggestions. Teachers worked in small groups to explore the blog. They discussed the affordances and constraints of using blogs in their professional development, learned the basics of subscribing to the blog, posting comments, and embedding links.

I suggested to the teachers that they subscribe to the blog to receive regular updates. I also suggested to the teachers that they communicate with other members of the blog, exchange ICT ideas, post ICT ideas and queries, provide links to other web content, use the ICT resources on the blog for classroom teaching of English, and use the blog as an integrated part of their professional development in ICT. Teachers could also ask for ICT assistance or suggestions from me or from other teachers, and also share their own ideas with other members of the blog. Teachers' individual and collaborative work was visible to all viewers as it was an open blog and membership was free.

Participant observations and note-taking during the ICT interactive workshops were helpful in knowing the ICT barriers and needs of English teachers in Mumbai for instructional and professional development purposes and their responses to education blogging. Also, it helped in identifying the resources that could be used to excite and motivate teachers of English to practice ICT integrated teaching. I used data collected through participant observation (field notes) to improve the design of the other methods I used in the study, such as interviews. By note-taking during observation, I evaluated the level of teachers' participation in the workshop discussions and validated the selection of 10 teacher-participants for the interviews. The duration of the workshops was 45-60 minutes.

\section{Questionnaires}

After the ICT interactive workshops, all teacher-participants completed questionnaires comprising openended questions. Open-ended questions have an engaging feature and they persuaded genuine responses and two-way communication from the participants (Patton, 2002). Also, the responses to open-ended questions could be thought of as a kind of written interview. Three open-ended questions were added to know the ICT attitudes, barriers and professional development needs of teachers. All 32 teacher-participants completed the questionnaires and it took them about 10-15 minutes.

\section{Interviews (semi-structured)}

The interview method is frequently used for qualitative data collection because it permits a researcher access into the beliefs and attitudes of participants (Lichtman, 2006; Patton, 2002). Two weeks after each ICT interactive workshop, I conducted face-to-face semi-structured interviews with 10 teacher-participants to examine their ICT attitudes and experiences post workshop and blog usage. The interviews in this study were semi-structured. The interviews took about 15 minutes to complete and were audio recorded and transcribed. For the reassurance of the teacher-participants, all 10 participants were allowed to read their interview transcripts after their interviews.

\section{Data analysis strategies}

Participant observation (field notes), open-ended questionnaires, interviews, and blog comments were analysed for emerging themes in a more interpretative way. I followed thematic analysis for qualitative data, the most common and relevant form of data analysis used in qualitative research (Bain \& McNaught, 2006). I identified patterns of meaning across my datasets that provided an answer to the research questions being addressed. Patterns were identified through a thorough process of familiarisation of data, coding, development of themes, and finally revision with the help of qualitative software program, QSR NVivo. The QSR NVivo program is frequently used in the qualitative analysis because of its efficacy in the management of data (Lichtman, 2006). The coding process is considered the heart of thematic analysis (Lichtman, 2006). Coding can be defined as "the process of organising the material into chunks or segments of text before bringing meaning to information” (Rossman \& Rallis, 1998; p. 171). Johnson and Christensen (2004) state that: "coding is the process of marking segments of data (usually text data) with symbols, descriptive words, or category names” (p. 502). 
Research findings were then analysed based on these combined themes (sub-categories) under their respective key areas (key categories). At the end of the coding process, key areas (categories) and themes (codes/sub-categories) were identified for analysis. When the major themes emerged as the main points of the investigation, they were then written up as part of the research findings. Finally, the codes were categorised to create a hierarchy of concepts or themes. Themes were refined in reference to the literature and validated through discussion and consultation with my supervisors. I coded the key area categories as A (teacher attitudes), B (ICT barriers), C (professional development needs) and D (blog potential for professional development). I also identified the similar/singular/varied patterns (themes/sub-categories) related to the key areas and sub-coded them as A1, B1, B2, C1, and D1 to address the research questions. The key areas and themes that emerged from the thematic analysis and coding of responses to ICT interactive workshop observations, questionnaires, interviews and blog comments are tabulated in Table 1.

Table 1

Key areas and themes

\begin{tabular}{|l|l|}
\hline \multicolumn{1}{|c|}{ DATA EXCERPT } & \multicolumn{1}{|c|}{$\begin{array}{c}\text { KEY AREAS AND } \\
\text { ASSOCIATED THEMES }\end{array}$} \\
\hline $\begin{array}{l}\text { A1. I think that the choice of technology adds a great deal to my } \\
\text { teaching of English, adds to my students' motivation for } \\
\text { learning and often helps me in presenting a topic in an exciting } \\
\text { and new way. }\end{array}$ & $\begin{array}{l}\text { A. Teacher attitudes } \\
\text { A1. Positive attitudes towards ICT }\end{array}$ \\
\hline $\begin{array}{l}\text { B1. We have yearly workshops in the school on basic ICT skills } \\
\text { for new teachers but it is not very useful for English teachers due } \\
\text { to general training. }\end{array}$ & $\begin{array}{l}\text { B. ICT barriers } \\
\text { B1. Ineffective professional } \\
\text { development practices } \\
\text { B2. I don't have much time left after class because of lesson } \\
\text { planning, teacher meetings, students' extra-curricular activities. } \\
\text { There is a lot of workload on me. I don't have time to prepare or } \\
\text { search ICT resources for teaching English. }\end{array}$ \\
$\begin{array}{l}\text { C1. For regular interaction of English teachers for planning, } \\
\text { sharing ideas and resources, school should set up its discussion } \\
\text { forum for subject teachers to share lesson plans and teaching } \\
\text { resources. }\end{array}$ & $\begin{array}{l}\text { C. Professional development needs } \\
\text { C1. School support and culture. }\end{array}$ \\
\hline $\begin{array}{l}\text { D1. There is no teamwork among teachers to use technology. I } \\
\text { always prepare my ICT resources on my own. } \\
\text { D1. The teachers in my school have more ICT knowledge than } \\
\text { me but very few English teachers share their ideas with each } \\
\text { other. }\end{array}$ & $\begin{array}{l}\text { D. Potential of blogging for } \\
\text { professional development } \\
\text { D1. Openness to sharing ICT } \\
\text { knowledge and skills }\end{array}$ \\
\hline
\end{tabular}

\section{Ethical considerations}

Creswell (2009) notes the researcher has an obligation to respect the rights, needs, values and desires of the informants. No major ethical issue, harm, risk, or possible hurt was anticipated from my proposed study. Prior to commencing any data collection, I submitted plain language statements to all the participating teachers and obtained informed written consent from all the teachers. Also, as an act of courtesy, I had taken a verbal consent for data collection from the principals and vice-principals of all the three schools. Since the participants were private school teachers, consent from India's, and more specifically, Mumbai's education board or committee was not required. Moreover, I assured my participants that the finding of my research would not affect their employment as any information they give would be solely used for the research purposes and would not be disclosed to their employer (school). Also, participation by teachers was completely voluntary and not related to their work duties. Before data collection, I asked participants' permission for audio recording (during interviews) and participant observations (during ICT interactive workshops). No reference to participants was made in the final report. Pseudonyms were used to maintain the participants' confidentiality. I also employed security measures to transport the research data back to Melbourne from Mumbai. All data was preserved and secured according to the university's research guidelines and requirements. 


\section{Findings}

\section{Positive attitudes towards ICT}

Most notably, teachers' attitudes towards ICT integrated teaching were positive. Teachers regarded ICT as an important and useful tool to help them convey or present their teaching interestingly as students looked forward to classes conducted with ICT as compared to the traditional and conventional methods of teaching. They acknowledged that ICT was effective and useful in the teaching of English and had a positive impact on their students' learning.

I think that the choice of technology adds a great deal to my teaching of English, adds to my students' motivation for learning and often helps me in presenting a topic in an exciting and new way. (Dipika)

I feel that ICT has made English teaching more enjoyable therefore English learning more enjoyable in the process. Technology keeps my students focused so I guess they'd be learning more. (Sunita)

\section{Ineffective professional development practices}

Although the schools conducted regular ICT training sessions for their in-service teachers, most teachers viewed their professional development practice as a series of inadequate, inappropriate and ineffective activities that were detached from their actual classroom teaching practice. Even after having gone through in-service training on ways of integrating ICT tools in the teaching of English, the teachers were not carrying out ICT integration in teaching and professional learning. Also, most teachers did not receive an in-depth and subject-specific pedagogical ICT training at the teachers' training colleges or universities where they were trained and therefore, they did not get opportunities to understand the relevant use of the ICT tools in the teaching of English. The following comments are representative of the teachers' view of the issue:

The ICT workshops we attend at our school don't give us adequate skills to enable English teachers to mix ICT in English teaching. (Jaya)

I have limited ICT knowledge. We have yearly workshops in the school on basic ICT skills for new teachers but it is not very useful for English teachers due to general training. (Fatima)

Their professional development experiences came in the form of workshops and courses that were delivered by outside experts, and received by teachers in isolation, without teacher interaction and follow-up. The teachers commented on the often-frustrating nature and lack of helpfulness of most of the professional development they had received. For the most part, teachers were not consulted about what would be most helpful and their professional development workshops focused mainly on ICT hardware and operation and were often led by people who had limited understanding of the English subject and the pedagogical implications of ICT in teaching English. As most teachers were not usually consulted for their professional development needs, they often perceived their professional development experience to be extraneous to the improvement of their teaching practice. This, in turn, made it difficult for the teachers to incorporate the knowledge and skills gained from the professional development experience in their practice.

\section{Lack of time}

A dominant theme throughout the findings is the issue of time. Pre-teaching activities like planning and preparing ICT-related lessons were all quite time-consuming for the teachers. Teachers also admitted that their workload (in and outside school) influenced their use of ICT in classrooms.

I don't have much time left after class because of lesson planning, teacher meetings, students' extra-curricular activities. There is a lot of workload on me. I don't have time to prepare or search ICT resources for teaching English. (Chetana) 
Moreover, teachers were burdened throughout the year with students’ assessments, markings, evaluations, school events, and extra-curricular activities. Teachers also had an out-of-school teaching workload. A comment from one of the teachers supports this barrier:

As a teacher, I have so much to do, even after school hours; something additional is possible only when all work together, not alone. (Dipika)

Furthermore, some teachers did part-time private tuitions and so even when ICT workshops were organised externally by their school, they never attended. One teacher explained:

It seems impractical and impossible to me. I can’t rely on the salary I get for being a teacher, so I have another job after school hours to be able to support my family. Even if I want to learn something new to improve my teaching or share ideas with other teachers online, I can’t, I just don't have time. Although I wish I could. (Nisha)

Teachers ICT usage was also influenced by the exam-oriented and result-oriented school culture where syllabus completion was the teachers' first priority.

[A]dding more activities or spending extra time on ICT teaching resources will sidetrack me from the primary purpose which is completing the syllabus before the end of the school. (Hansa)

Pre-teaching activities like planning and preparing ICT related lessons were all quite time-consuming. Teachers also needed time for troubleshooting technical glitches in the classroom. Lessons that integrate ICT were a time-consuming activity from the teachers' perspective and mentioned by most teachers on several occasions of data collection:

English lessons with the use of technology require too much time. I need to find materials, websites, check whether they are relevant and all this by my own. I can't just prepare them like that. I need at least 1-2 days and I have time only on a Sunday which I want to keep for my family. (Varsha)

\section{School support and culture}

Teachers also expressed the need for having frequent networking, collaboration, and follow-up within their subject community. Teachers asked for a school environment where the school recognises the importance of subject teachers' needs and involvement in professional development decision-making and implementation. They suggested that the school could play an active part in supporting and promoting this culture of collaboration and innovation in professional development that was subject-specific and contextspecific.

For regular interaction of English teachers for planning, sharing ideas and resources, school should set up its discussion forum for subject teachers to share lesson plans and teaching resources. (Chetana)

School must build a virtual community of English teachers as learners. Subject teachers must often get together to discuss lesson plans and weekly planning. The same can be done to share English teaching resources. (Varsha)

\section{Openness to sharing ICT knowledge and skills}

Most teachers in this study considered the sharing of teaching ideas with each other as a professional development activity and valued sharing activities because they were considered to be directly related to the classroom and their school context. However, the teachers accepted often working in isolation from other subject teachers in their school.

English activities can be quickly prepared using ICT when English teachers work together as a team. But sadly that's not happening in my school. (Varsha) 
As a teacher, I have so much to do, even after school hours; something additional is possible only when all work together, not alone. (Dipika)

There is no teamwork among teachers to use technology. I always prepare my ICT resources on my own. (Tina) Questionnaire

I am new in this profession and not very good with technology. The teachers in my school have more ICT knowledge than me but very few English teachers share their ideas with each other. (Nitya)

Most teachers found blogs to be useful for teacher teamwork, collaboration, and sharing of ICT ideas.

I believe that it encourages us socially, because we find the opportunity, ease and freedom to deliver our ideas possibly without the fear of being judged or evaluated, unlike a training workshop. It will possibly make us more secure in that environment. (Madhu)

You share your ideas with the one source and simultaneously with all the blog members. I think that's really amazing. You just ask question everybody wants an answer for. And the answer to your query is the answer for everybody. (Indira)

Teachers proactively participated in professional learning on my blog. Out of the 32 participants in this study, 20 teachers $(62.5 \%)$ subscribed to the blog. Figure 2 contains comments made by teachers on the blog.

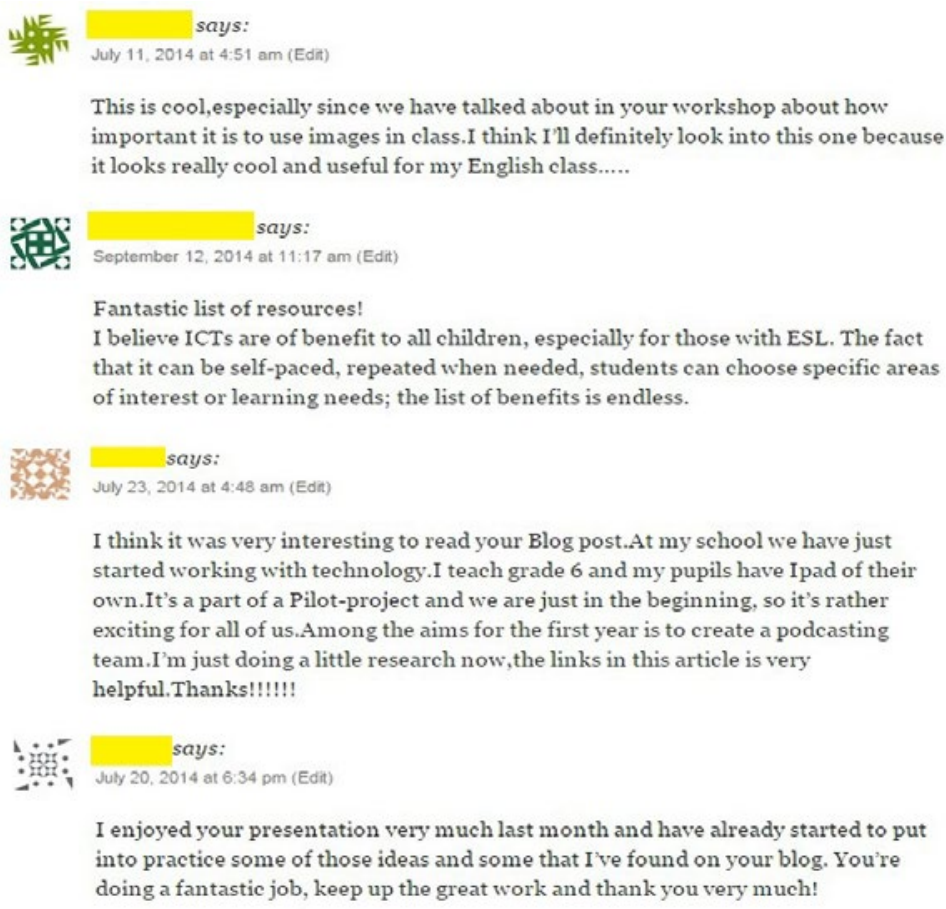

I think it was very interesting to read your Blog post.At my school we have just started working with technology.I teach grade 6 and my pupils have Ipad of their own.It's a part of a Pilot-project and we are just in the beginning, so it's rather exciting for all of us.Among the aims for the first year is to create a podcasting team.I'm just doing a little research now, the links in this article is very helpful.Thanks!!!!!!

I enjoyed your presentation very much last month and have already started to put into practice some of those ideas and some that I've found on your blog. You're doing a fantastic job, keep up the great work and thank you very much!

These speakers are excellent! Thanks for sharing ! I used it in one of my poetry classes for grade 8 students. This is something new for them.......so initially I was not sure.... but they thoroughly enjoyed it......... since the content is very mentally and emotionally provocative......this led to a good discussion post viewing.....thanks! says: January 15, 2015 at $10: 09 \mathrm{pm}$ (Edit)

Very helpful for discussion or debate class........ used a couple of ted talks in my english class last week....students enjoyed it thoroughly...very good tool to improve their public speaking skills also, thanks Reply

Figure 2. Screenshots of teachers' blog comments 
Teacher engagement and participation on the blog for their professional learning decreased with the passage of time. Although ideally, the sense of community would bring English teachers back to the blog often to check for new posts and responses, and although blogging could enable them to work in teams interactively, teachers' participation at the end of the academic year in Mumbai was the lowest, and their participation was much less than that of the other periods of participation. Table 2 explains the same.

In spite of receiving email notifications through blog subscriptions, many teachers did not post their ICT ideas on the blog; the ideas that they had shared earlier during the face-to-face workshops. Also, although teachers interacted with me through their comments on the blog posts and reflected on their classroom practices, very few blog comments made by the participants were related to providing suggestions or advice to other teachers' queries, offering reflections, or collaborating with other teachers. The majority of blog comments made by teachers was related to either appreciation and encouragement or sharing lessons and resources.

Table 2

Teachers' blog entries

\begin{tabular}{|c|c|c|c|c|c|c|c|c|}
\hline PERIOD & JULY & AUG & SEPT & OCT & NOV & DEC & JAN & FEB \\
& 2014 & 2014 & 2014 & 2014 & 2014 & 2014 & 2015 & 2015 \\
\hline Number of teacher-comments & 9 & 5 & 6 & 1 & 2 & 4 & 3 & 1 \\
\hline
\end{tabular}

After the mid-term examinations and festive holidays in Mumbai during the period of October 2014, blog inputs by teachers significantly decreased, and in comparison to the months of July, August, and September of 2014, teachers in this study became less active on the blog. The teachers' responses do provide an insight (discussed in the next section) into the impediments that English teachers in this study faced pertaining to their professional development and ICT integrated teaching.

\section{Discussion}

Findings revealed that the majority of the teachers had positive attitudes towards ICT integrated teaching and professional development. The teachers also believed ICT is useful for better student learning. This resonates with similar findings identified by (Bordbar, 2010; Kulkarni, 2012; Kumar \& Kumar, 2003; Narasimham, 2012; Rajasekar \& Vaiyapuri, 2007). These studies establish that majority of the teachers have positive attitudes towards using ICT in teaching. The teachers in this study also had positive attitudes towards being part of an online professional learning community and were interested in collaborative blogbased learning. This finding reflects findings from other studies (Kim, 2008; Loving et al., 2007; Lunyal, 2012; Murugaiah, 2010; Prestridge, 2014; Ray \& Hocutt, 2006; Toner, 2004; Zandi et al., 2014), which show that teachers mostly had positive attitudes towards educational blogging for professional development. The effective implementation of a new form of professional learning, such as a blog-based professional development, clearly depends on the teachers' readiness to engage with ICT. The first essential prerequisite of this blog-based professional development study then is to develop positive beliefs in teachers about blog-based professional development that includes the idea that teachers can lead their own professional development through online professional interaction, mutual sharing, and collaboration. The already existing positive attitude of teachers in my study towards blogs was an added advantage to the implementation of the blog. Their positive attitude was a catalyst to make changes in their professional learning more inviting for them. This positive finding really stands out and gives rise to a hopeful consideration of the future prospects of blog-based professional development; and the need for state, schools, and teachers themselves, to carefully regard its potential in overcoming the major ICT barriers. The blog-based approach to professional development for English teachers in Mumbai shows potential as it generated new learning opportunities for teachers in this study who were also largely enthusiastic about their new experience of online learning. However, the blog was not used extensively and consistently by teachers for their professional development as findings demonstrate that teachers' engagement in blogbased professional development reduced with time. So what issues hindered their online reflection, networking and collaboration over a period of time?

Online communities are successful when time is provided for teachers to test new learning methods and to receive follow-up support as they face problems of implementing changes (Duncan-Howell, 2009; 
Ingvarson, Meiers, \& Beavis, 2005). A longer period is needed to engender an online and collaborative learning community of teachers which supports critical reflection, teacher involvement, teacher control, backed by the school support for social learning in which the cognitive activities of professional development can be complemented by social connectivity to build a more collaborative network of teachers (Garet et al., 2001; Power, 2011). Maybe teachers in my study needed more time to feel comfortable and confident about using a social learning tool even though they were excited about their new learning opportunity.

Based on the professional development practices imposed on teachers by their schools, teachers in this study were not exposed to ICT integrated professional learning practices, relevant to their subject needs and preferences. They merely followed what they were told by their school management. The findings also concur with Pandit-Narkar's (2012) study, which points out that educational administrators and school managers in India seem to view teacher professional development "mainly in terms of achieving better examination results” (p. 31), but a better dialogue between the educational administrators, school managers and teachers is necessary for sustained teacher development. Teachers also in my study needed more school support and encouragement to practice teacher-centred and teacher-controlled professional development.

The aspect of knowledge construction through collaboration was limited among the teachers in this study. A review of earlier teacher comments on the blog shows some personal, interactive, and collaborative teacher discourse. However, results indicate little evidence of the development of a more interactive and collaborative approach. Collaboration between teachers was not yet a critical component of their professional development, maybe because schools were too hierarchy-oriented to allow teacher-directed and teacher-controlled professional development. Teachers' views reveal that active participation in knowledge sharing was unachievable in part because of the conventional structure of working in Mumbai schools that was based on autonomous classrooms in which each teacher was working as an isolated practitioner, and the schools' sole focus on syllabus completion and exam results, made it complicated for teachers to practice innovative and collective learning processes with ICT. In this respect, my study reinforces Somekh (2008), who advocates that absence of school support, lack of organisational change, lack of access time, and prevailing views on education are not simple issues. They are limiting many innovative forces on the pathway to effective professional learning in ICT, in addition to frustrating already demotivated teachers.

This study supports the claims of Bate (2010), Groff and Mouza (2008), and Tearle (2003) who suggest that discipline-specific technologies, educational philosophy of the teacher, and the socio-cultural context of the school should be included explicitly within professional development programs initiated by the school. Similar to the study of Scott and Scott (2010), the findings of this study also reveal that current teacher professional development in Mumbai mostly emphasises a directive method and prescriptive information dissemination with little emphasis on teachers' interaction and collaboration. Although I had set up a blog-based forum for all the teacher participants and regularly posted subject-specific ICT ideas and resources, most responses from teachers were inclined more towards (passive) appreciation rather than reflection, networking and collaboration. My findings also reflect the findings in Gupta's (2014) study on the use of social media for the professional development of English teachers, which reveals that the use of Web 2.0 technologies for the professional development of teachers is yet to gain adequate popularity in India. Based on formal face-to-face professional development practices imposed on teachers by their schools, teachers in this study were not supported by their schools to practice collaborative professional development. The value of teacher reflection, networking, and collaboration cannot be easily reconciled in education settings where school-mandated professional development programs traditionally supported product over process. Teachers in India need more school support and encouragement to practice teachercentred and teacher-controlled professional development. Teachers are unlikely to transform their teaching (and learning) if their ICT skills are isolated from their pedagogical inquiries (Prestridge, 2008). Current research findings coincide with studies by Padwad (2006, 2008) and Stiler and Philleo (2003), which report that inappropriate ICT training (both pre-service and in-service), that does not link ICT with pedagogy, results in low levels of ICT use by teachers. Moreover, like the works of Bedadur (2012), Duncan-Howell (2009), and Holmes et al. (2013), this study suggests that professional development has to be linked to teaching practice and teacher needs for success. A change in the professional development practices can be possible with a change in attitudes and perceptions of teachers and their schools; when all the agents of change would be involved to bring about a change. 
There is a lot that English teachers in Mumbai can learn through online communities, taking advantage of each other's teaching experience and ICT practices in the classrooms. Padwad and Dixit's (2014) Think Tank project in India revises the role of teacher professional development in India from something controlled by the state to a more relevant and comprehensive practice in which teachers took centre stage. Similarly, this study reiterates that instead of an authoritative structure of professional development controlled by less representative and less inclusive groups, for example expert committees (which are so typical in the Indian scenario), a collaborative structure of collective professional development involving all possible stakeholders is an effective way of making better sense of the challenges and solutions in professional development. Moreover, professional development initiatives such as this will be more relevant when they are strongly influenced by local cultures and situated appropriately in the socio-cultural environments of the school. According to Prince and Barrett (2014): “'In an Indian teacher's case, the school principal, the block or district education officer, the state machinery or even national policy might man the travel desk'” (p. 23). Teacher professional development thus needs to be seen as holistic and decentralised, with a focus on professional discourse and a climate of interaction for the teachers (Hawkes, 2000; Light, 2009; Padwad \& Dixit, 2012).

The findings are congruent with Carr and Chambers' (2006) who identify two major barriers to online communities of teachers: schools undervalue the significance of collective reflection and sharing of practice in the teacher community, and therefore classroom teachers do not find any purpose or motivation to use online communications tools as an integral part of their professional practice. Taking a whole school ICT leap can be a major challenge, and teacher professional development is generally seen as the bridge. But this bridge will be less frequently built through traditional professional development programs. While most approaches to teacher professional development concentrate on skill development of individual teachers, a previous study by Popovic and Subotic (2012) and the findings of the current study describe a school-based approach that focuses on teachers' ICT attitudes, beliefs, and confidence, and on building a reflective and collaborative culture within the school that supports teacher contribution, not conformity. This research presents findings, similar to the findings of Borko (2004), Pandit-Narkar, (2012), Phelps, Graham, and Thornton (2006), and Phelps, Graham, Watts, and O'Brien, (2006), which indicate that significant outcomes of time and support can be achieved by schools through a bottom-up approach, not only relevant to ICT learning and integration by the teachers but in building a whole-school professional learning community which promotes collaborative and supportive partnerships between subject teachers.

Professional development activities that change the outdated teaching-learning practices of teachers, cultivate role changes, boost teacher confidence and morale, improve their working conditions, and reduce their workload, can rekindle their enthusiasm for learning and expand their ICT knowledge and skills. This study investigates a promising ICT approach to professional development for English teachers in Mumbai. Of course, ultimately, it is important to keep in mind and to ensure that the aim of this research is not to promote technology for technology's sake. Rather, the aim is to introduce a paradigm shift in the in-service training system for English teachers in Mumbai; a highly centralised and heavily bureaucratic environment. The discussion of the findings reveals that sufficient time and supportive school culture can help the teachers to be more self-directed in embracing new technologies and driving their actual learning.

\section{Implications}

Teachers in this study viewed their professional development as a series of inadequate, inappropriate, and ineffective activities that were detached from their actual classroom teaching practice and needs. They accepted often working in isolation from other subject teachers in their school. However, they considered sharing of ICT ideas with each other as a professional development activity and considered it to be related to their classroom teaching practice and needs. Teachers expressed the need for having frequent networking, collaboration, and follow-up within their subject community. They asked for a school environment where the school recognised the importance of subject teachers' needs and involvement in professional development decision-making and implementation.

Teachers considered blogs to be useful for teacher teamwork, collaboration, and sharing of ICT ideas. They proactively participated in professional learning on my blog; however, the same could not be said with the passage of time as the extent of their blog-based teacher networking and collaboration for professional learning faded with time. A dominant theme throughout the findings was the issue of time. Pre-teaching activities like planning and preparing ICT-related lessons were all quite time-consuming for the teachers. 
Many teachers also admitted that their workload (in and outside school) influenced their use of ICT in classrooms. Some teachers did not wish to integrate ICT into English lessons because of their focus on examinations and syllabus completion. Findings indicate that the difficulties faced by teachers in including ICT in teaching and professional learning also are the result of hierarchical school organisation, the lack of genuine training for incorporating subject-specific ICT resources, and lack of collaborative school culture. Teachers' ICT practices were deeply influenced by a heavy workload, tight schedule, and exam-oriented school culture. Blog-based professional learning could help teachers to overcome those influences and guide their own learning through collaboration.

The social environment of online activities for professional development is quite different from in-person interactions, therefore requiring new skills and attitudes in teachers. As teachers continue through their careers they will need guidance on new skills and professional understanding, provided that the culture of the school enables this. Therefore, it would be useful to include a professional learning component that will teach participants not only how to collaborate to learn but also learn to collaborate. Teachers can also be supported and monitored while using web tools in their own learning situations. However, it is most important that the school systems are in place to provide these professional development programmes and to support the teachers' implementation of them in their learning. Schools should include a changed vision for their teachers' professional development that nurtures decision-making, ownership, responsibility and development of learning by teachers themselves, rather than implementing systems solely based on long established policies and practices.

Current findings have implications for policy changes in India that disregard the sole reliance on short-term learning; which give unsatisfactory encouragement for teachers to collaborate and does not result in benefits to the wider teaching-learning community. Although teachers complained about excessive workload and lack of time, teachers embraced (while only for a short period of time) the social and collaborative aspects of blog-based professional development as a time-saving medium of learning. Though blogs offer a collaborative opportunity to help teachers grow professionally, its future success is entirely dependent on the motivation of the participants through the support of their schools. Schools, in this case, can be enablers of new forms of professional development for their teachers. Schools need to be more open to change and support online networking and collaboration for teacher professional development. The schools should provide teachers with more practical opportunities based on their needs and preferences that relate ICT to pedagogy, and provide more time and ongoing support to the teachers so that they can adapt themselves to new learning environments.

\section{Conclusion}

Teachers in this study still had positive attitudes towards integrating ICT into instruction regardless of their ICT background. They preserved these positive feelings despite receiving insufficient ICT training from the schools where they worked. They considered ICT as a viable educational tool that could bring about different improvements to their schools and classrooms. Teachers' positive attitude towards ICT is important as this may influence them towards adopting new and innovative forms of professional learning that are ICT enriched, that is, using ICT to learn about ICT.

The knowledge and skills a teacher possesses and the knowledge and skills she applies in teaching are the most important influences on what students learn. But, teachers in this study were overloaded, overburdened, not very motivated, insufficiently trained, and they frequently dealt with difficult working conditions. Despite being aware that by using online networking and collaboration, teachers could have easily shared authentic ICT resources, saved time and effort, reflected on their ICT experiences, and collaborated with other teachers to use ICT more effectively in the classroom, the teachers could not adopt blogs as the long-term practice for their professional development.

The findings of my research resonate those Padwad and Dixit (2014) reported from their study of innovative professional development for English teachers in India, and identified that making provision for adequate time, breaking the hierarchy within the school system, and ensuring continuity and synergy between different formal and informal elements of professional development are important for the success of future professional development initiatives for teachers in India. Although it is difficult to make a convincing case in an Indian school set-up that better professional learning is one that teachers themselves create and 
manage, compared to a trainer-led professional development, blogs are a lot easier to produce, maintain, update and use, all controlled and driven by teachers themselves; a compelling argument for school managers and policy makers in India. Incomprehensibly, achieving a more useful practice of teacher professional development involves a struggle against these limitations, yet it might likewise help to create a school culture that is more welcoming to teacher-led learning. The time and resources schools put into building and maintaining a blog-based professional learning community for their teachers will benefit their teachers as they will engage in ongoing learning and purposeful collaboration that can have a lasting impact on their classroom practice and their students’ learning.

\section{References}

Avison, D., Baskerville, R., \& Myers, M. (2001). Controlling action research projects. Information Technology and People, 14(1), 28-45. https://doi.org/10.1108/09593840110384762

Bain, J. D., \& McNaught, C. (2006). How academics use technology in teaching and learning: understanding the relationship between beliefs and practice. Journal of Computer Assisted Learning, 22(2), 99-113. https://doi.org/10.1111/j.1365-2729.2006.00163.x

Baskerville, R., \& Myers, M. (2004). Special issue on action research in information systems: Making IS research relevant to practice - foreword. MIS Quarterly, 28(3), 329-335. Retrieved from http://citeseerx.ist.psu.edu/viewdoc/download?doi=10.1.1.58.4699\&rep=rep1\&type=pdf

Bate, F. (2010). A bridge too far? Explaining begining teachers' use of ICT in Australian schools. Australasian Journal of Educational Technology, 26(7), 1042-1061. https://doi.org/10.14742/ajet.1033

Bedadur, N. (2012). A design-based study on using M learning for CPD. In R. Bolitho \& A. Padwad (Eds.), Continuing professional development: Lessons from India (pp. 88-95). New Delhi: British Council. Retrieved from https://www.teachingenglish.org.uk/sites/teacheng/files/CPD\%20Lessons\%20book.pdf

Bell, A., \& Morris, G. (2009). Engaging professional learning in online environments. Australasian Journal of Educational Technology, 25(5), 799-713. https://doi.org/10.14742/ajet.1116

Bolitho, R., \& Padwad, A. (Eds.). (2012). Continuing professional development: Lessons from India. New Delhi: British Council.

Bordbar, F. (2010). English teachers' attitudes toward computer-assisted language learning. International Journal of Language Studies, 4(3), 27-54.

Borko, H. (2004). Professional development and teacher learning: Mapping the terrain. Educational Researcher, 33(8), 3-15. https://doi.org/10.3102/0013189X033008003

Carr, N., \& Chambers, D. P. (2006). Cultural and organisational issues facing online learning communities of teachers. Education and Information Technologies, 11(3), 269-282. https://doi.org/10.1007/s10639-006-9024-2

Chattopadhyay, K. (2013, July). Future directions for digital literacy development of Indian educators. Paper presented at the WorldCALL 2013 Conference. Glasgow. Retrieved from http://arts.ulster.ac.uk/worldcall2013/userfiles/file/shortpapers.pdf

Cohen, L., Manion, L., \& Morrison K. (2007). Research methods in education (6th ed.). London: Routledge Falmer.

Creswell, J. W. (2009). Research design: Qualitative, quantitative, and mixed methods approaches (3rd ed.). London: Sage Publications.

Denzin, N. K., \& Lincoln, Y. S. (1994). Handbook of qualitative research. Thousand Oaks, CA: Sage.

Duncan-Howell, J. (2009). Teachers making connections: Online communities as a source of professional learning. British Journal of Educational Technology, 41(2), 324-340. https://doi.org/10.1111/j.14678535.2009.00953.x

Flyvbjerg, B. (2011). Case study. In N. K. Denzin \& Y. S. Lincoln (Eds.), The Sage Handbook of Qualitative Research (pp. 301-316). Thousand Oaks, CA: Sage.

Garet, M. S., Porter, A. C., Desimone, L., Birman, B. F., \& Yoon, K. (2001). What makes professional development effective? Results from a national sample of teachers. American Educational Research Journal, 38(4), 915-945. https://doi.org/10.3102/00028312038004915

Groff, J., \& Mouza, C. (2008). A framework for addressing challenges to classroom technology use. Association for the Advancement of Computing in Education Journal, 16(1), 21-46. Retrieved from http://www.jengroff.net/pubs_files/i5Framework_GROFF-MOUZA.pdf 
Gupta, D. S. (2014). Social media for teachers of English: A hub for professional development. Research Journal of English Language and Literature, 2(2), 34-38. Retrieved from http://www.rjelal.com/2.2.14/34-38.pdf

Hall, H., \& Davison, B. (2007). Social software as support in hybrid learning environments: The value of the blog as a tool for reflective learning and peer support. Library and Information Science Research, 29(2), 163-187. https://doi.org/10.1016/j.lisr.2007.04.007

Hawkes, M. (2000). Structuring computer-mediated communication for collaborative teacher development. Journal of Research and Development in Education, 33(4), 268-284.

Henderson, M. (2004, June). Sustaining the professional development of teachers through a virtual learning environment: Promoting effective teaching with ICT. Paper presented at the ED-MEDIA, World Conference on Educational Multimedia, Hypermedia \& Telecommunications, Lugano, Switzerland.

Henning, E., van Rensburg, W., \& Smit, B. (2004). Finding your way in qualitative research. Pretoria: Van Schaik.

Hew, K. F., \& Brush, T. (2007). Integrating technology into K-12 teaching and learning: Current knowledge gaps and recommendations for future research. Educational Technology Research and Development, 55(3), 223-252. https://doi.org/10.1007/s11423-006-9022-5

Holmes, K., Preston, G., Shaw, K., \& Buchanan, R. (2013). 'Follow’ me: Networked professional learning for teachers. Australian Journal of Teacher Education, 38(12), 55-65. https://doi.org/10.14221/ajte.2013v38n12.4

Ingvarson, L., Meiers, M. \& Beavis, A. (2005). Factors affecting the impact of professional development programs on teachers' knowledge, practice, student outcomes \& efficacy. Education Policy Analysis Archives, 13(10), 1-28. Retrieved from http://research.acer.edu.au/cgi/viewcontent.cgi?article=1000\&amp;context=professional_dev

Johnson, R. B., \& Christensen, L. (2004). Educational research: Quantitative, qualitative, and mixed approaches (2nd ed.). Boston, MA: Pearson Education.

Kim, H. N. (2008). The phenomenon of blogs and theoretical model of blog use in educational context. Computers \& Education, 51(3), 1342-1352. https://doi.org/10.1016/j.compedu.2007.12.005

Kulkarni, M. V. (2012). A study on secondary school teachers' attitude towards using new technologies in education. Indian Streams Research Journal, 2(8), 1-6. Retrieved from http://isrj.org/UploadedData/1354.pdf

Kumar, P., \& Kumar, A. (2003). Effect of a web-based project on pre-service and in-service teachers' attitudes toward computers and technology skills. Journal of Computing in Teacher Education, 19(3), 87-92. https://doi.org/10.1080/10402454.2003.10784468

Lichtman, M. (2006). Qualitative research in education: A user's guide. Thousand Oaks, CA: Sage Publications.

Light, D. (2009). The role of ICT in enhancing education in developing countries: Findings from an evaluation of the Intel Teach Essentials course in India, Turkey, and Chile. Journal of Education for International Development, 4(2), 1-15. Retrieved from http://www.equip123.net/JEID/articles/4_2/Light.pdf

Loving, C, C., Schroeder, C., Kang, R., Shimek, C., \& Herbert, B. (2007). Blogs: Enhancing links in a professional learning community of science and mathematics teachers. Contemporary Issues in Technology and Teacher Education, 7(3), 178-198. Retrieved from http://www.citejournal.org/volume-7/issue-3-07/science/blogs-enhancing-links-in-a-professionallearning-community-of-science-and-mathematics-teachers/

Lunyal, V. (2012). Collaborative spaces on the Web and language teaching: Blogs and Wikis. Language and Language Teaching, 1(1), 46-54. Retrieved from http://www.jnu.ac.in/Library/Language\%20\&\%20Language\%20Teaching\%20\%20Inaugural\%20Issue.pdf

Merriam, S. B. (1998). Qualitative research and case study: Applications in education. San Francisco, CA: Jossey-Bass.

Miles, M. B., \& Huberman, A. M. (1994). Qualitative data analysis: An expanded sourcebook (2nd ed.). Thousand Oaks, CA: Sage Publications.

Mitakshara, K. (2009). Policy coherence in the application of ICTs for education in India \& South Asia. India: Price Waterhouse Coopers.

Murugaiah, P. (2010). Blogging in teacher professional development: Its role in building computerassisted language teaching skills. International Journal of Education and Development Using 
Information and Communication Technology (IJEDICT), 6(3), 73-87. Retrieved from http://ijedict.dec.uwi.edu/viewarticle.php?id=1047

Narasimham, Y. (2012). Attitude of the secondary school English language teachers towards using Information and Communication Technology (ICT). International Journal of Multidisciplinary Educational Research, 1(1), 269-272. Retrieved from http://ijmer.in/pdf/volume1-issue1-2012/269272.pdf

Padwad, A. (2006). English teachers' clubs: An experiment in teacher development in India. SPELT Quarterly, 21(4), 31-34.

Padwad, A. (2008). Teacher development: A worm's eye view. The Teacher Trainer, 22(3), 22-24.

Padwad, A., \& Dixit, K. (2008). Impact of professional learning community participation on teachers' thinking about classroom problems. TESL - EJ, 12(3). Retrieved from http://www.teslej.org/wordpress/issues/volume12/ej47/ej47a10/

Padwad, A., \& Dixit, K. (2012). Multiple stakeholders’ views of continuing professional development. In R. Bolitho \& A. Padwad (Eds.), Continuing professional development: Lessons from India (pp. 1122). New Delhi: British Council.

Padwad, A., \& Dixit, K. (2014). Continuing professional development policy 'Think tank': An innovative experiment in India. In D.Hayes (Ed.), Innovations in the continuing professional development of English language teachers (pp. 249-268). London: British Council. Retrieved from https://www.teachingenglish.org.uk/sites/teacheng/files/E168\%20Innovations\%20in\%20CPD_FINAL \%20V2\%20web.pdf

Pandit-Narkar, M. (2012). From top-down intervention to bottom-up initiative: Teacher development in Nellore. In R. Bolitho \& A. Padwad (Eds.), Continuing professional development: Lessons from India (pp.31-39). New Delhi: British Council.

Patton, M. Q. (2002). Qualitative evaluation and research methods (3rd edition). London: Sage.

Phelps, R., Graham, A., \& Thornton, P. (2006). Technology Together: Getting whole schools involved with ICT through a meta-cognitive approach. The Australian Educational Leader, 28(1), 22-24. Retrieved from http://epubs.scu.edu.au/cgi/viewcontent.cgi?article=1026\&context=educ_pubs

Phelps, R., Graham, A., Watts, L., \& O'Brien, A. (2006, October). Technology together: Supporting whole-schools to become capable learning communities. Paper presented at the Australian Computers in Education Conference (ACEC) 2006, Cairns.

Popovic, D., \& Subotic, L. (2012). Continuing professional development of teachers in Montenegro. In R. Bolitho \& A. Padwad (Eds.), Continuing professional development: Lessons from India (pp. 108-114). New Delhi: British Council.

Power, A. (2011). Against short term professional learning. Issues in Educational Research, 21(3), 295309. Retrieved from http://www.iier.org.au/iier21/power.pdf

Prestridge, S. J. (2008, September-October). Teachers orientation towards ICT professional development. Paper presented at the Australian Computers in Education Conference, Canberra.

Prestridge, S. J. (2014). Reflective blogging as part of ICT professional development to support pedagogical change. Australian Journal of Teacher Education, 39(2), 70-86. https://doi.org/10.14221/ajte.2014v39n2.4

Prince, E., \& Barrett, A. (2014). Continuing professional development in action: An Indian experience. In D.Hayes (Ed.), Innovations in the continuing professional development of English language teachers (pp. 19-44). London: British Council.

Rajasekar, S., \& Vaiyapuri, R. P. (2007). Higher secondary school teachers’ computer knowledge and their attitude towards computer. Journal of All India Association for Educational Research, 19(1), 7076. Retrieved from http://www.aiaer.net/ejournal/vol19107/18.htm

Ray, B. B., \& Hocutt, M. M. (2006). Teacher-created, teacher-centered weblogs: Perceptions and practices. Journal of Computing in Teacher Education, 23(1), 11-18. Retrieved from http://files.eric.ed.gov/fulltext/EJ876914.pdf

Reddy, P.S. (2012). Problems in teaching/learning English as a second language in India. Language in India, 12(2), 781-790. Retrieved from http://www.languageinindia.com/feb2012/srinivasulueslfinal.pdf

Rossman, G., \& Rallis, S. F. (1998). Learning in the field: An introduction to qualitative research. Thousand Oaks, CA: Sage.

Sari, E., Lim, C.P., Pagram, J. (2010, August). Online learning community for teacher professional development (OLC4TPD): An innovative approach for supporting in-service teacher professional development practices in Indonesia. Paper presented at the Puslitjaknov Symposium 2010, Development, Research and Innovation Body, Ministry of National Education Indonesia, Jakarta. 
Scott, D., \& Scott, S. (2010). Innovations in the use of technology and teacher professional development. In J. O. Lindberg \& A. D. Olofsson (Eds.), Online learning communities and teacher professional development: Methods for improved education delivery (pp. 169-189). Hershey, PA: IGI Global.

Somekh, B. (2008). Factors affecting teachers' pedagogical adoption of ICT. In J. Voogt \& G. Knezek (Eds.), International Handbook of Information Technology in Primary and Secondary Education. London: Springer. https://doi.org/10.1007/978-0-387-73315-9

Stiler, G. M., \& Philleo, T. (2003). Blogging and blog spots: An alternative format for encouraging reflective practice among pre-service teachers. Academic Research Library 123(4), 789-798.

Tearle, P. (2003). Enabling teachers to use information and communication technology for teaching and learning through professional development: Influential factors. Teacher Development, 7(3), 457-471. Retrieved from http://www.tandfonline.com/doi/pdf/10.1080/13664530300200209?needAccess=true

Toner, M. (2004). 'Blogs' help educators share ideas, air frustrations. Education Week, 23(18), 8-10. Retrieved from http://www.edweek.org/ew/articles/2004/01/14/18blogs.h23.html

Zandi, P., Thang, S. M., \& Krish, P. (2014). Teacher professional development through blogging: Some preliminary findings. Procedia - Social and Behavioral Sciences, 118(19), 530-536. https://doi.org/10.1016/j.sbspro.2014.02.072

Corresponding author: Atiya Khan, atiya.khan@rmit.edu.au

Australasian Journal of Educational Technology (c) 2017.

Please cite as: Khan, A. (2017). Blog-based professional development of English teachers in Mumbai: The potential of innovative practice under scrutiny. Australasian Journal of Educational Technology, 33(4), 88-106. https://doi.org/10.14742/ajet.2784 